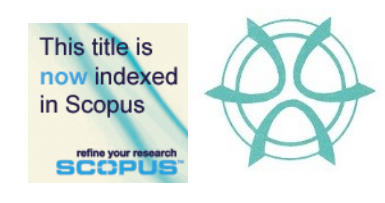

\title{
THE BEHAVIOUR OF HOUSEHOLDS TOWARDS ELECTRICITY CONSUMPTION: A CASE STUDY AT SEREMBAN
}

\author{
Saraswathy Kasavan ${ }^{1}$, Sharif Shofirun Bin Sharif Ali $^{2} \&$ Rusinah Siron ${ }^{3}$ \\ ${ }^{1}$ Institute of Energy Policy and Research (IEPRe), \\ UNIVERSITI TENAGA NASIONAL \\ ${ }^{2}$ School of Government (SoG), \\ UNIVERSITI UTARA MALAYSIA \\ ${ }^{3}$ College of Energy Economics and Social Sciences (CES), \\ UNIVERSITI TENAGA NASIONAL
}

\begin{abstract}
Understanding energy consumption behaviours among households is an effective way to encourage energy conservation and improve energy efficiency. This article examines households' knowledge, awareness, commitment, attitude, and behaviour towards electricity consumption. The sample of the study consists of 360 urban households in an intermediate city, Seremban. The findings reveal that cost-saving via government initiatives is a crucial factor influencing the households' energy consumption knowledge. The correlation analysis also revealed that knowledge, awareness, commitment, and attitude correlated significantly with the households' electricity consumption behaviour. The evidence suggests that the government and power companies implement strict regulations and technological advances to promote energy conservation and improve energy efficiency among households. The findings can better understand where attention should be directed and the measures for long-term energy conservation, climate change mitigation, and sustainable development.
\end{abstract}

Keywords: Household; behaviour; electricity consumption; knowledge, awareness, commitment, attitude

\footnotetext{
${ }^{2}$ Senior Lecturer at Universiti Utara Malaysia. Email: sshofirun@uum.edu.my
} 
Saraswathy Kasavan, Sharif Shofirun Bin Sharif Ali \& Rusinah Siron

The Behaviour of Households Towards Electricity Consumption: A Case Study at Seremban

\section{INTRODUCTION}

Households were considered as the most significant electricity consumers. Household electricity consumption was influenced by various factors, such as socio-economic profile, housing characteristics, and appliances' ownership (Permana et al., 2013). A recent study by Yalcintas and Kaya (2017) focused on the roles of income, price, and household size on residential electricity consumption in Hawaii. Chen (2017) found that gross domestic product (GDP), employment rates, residential space, and energy labeling scheme significantly influenced residential electricity consumption in Taiwan. Households are considered significant contributors to greenhouse gas emissions; their electricity consumption has led to global warming due to a complex series of interactions between socioeconomic, dwelling, and appliances ownership in electricity consumption.

As in Peninsular Malaysia, the domestic users represented approximately $82 \%$ (total 7.8 million) of the total electricity consumption (Rahman et al., 2017). Household electricity consumption per capita in Malaysia rapidly increased from $626 \mathrm{kWh} /$ person in 2000 to $4549 \mathrm{kWh} /$ person in 2016 (Energy Commission, 2021). The electricity sector depends mainly on fossil fuel resources, such as diesel, coal, and natural gas (accounting for $77.27 \%$ or $23,518.10 \mathrm{MW}$ ) (Yong et al., 2019). While large-hydro power contributes to electricity generation around $18.78 \%$ (5716.10 MW), only 3.96 per cent (1205.20 MW) is derived from renewable energy sources, such as biomass and biogas solar. The electricity sector has produced a significant emission from their power plants because burning fossil fuel produces greenhouse gases such as $\mathrm{CO}_{2}, \mathrm{SO}^{2}$, and $\mathrm{NOX}$.

Behavioural change towards the green approach is vital to reduce environmental problems and energy consumption. Therefore, understanding household consumption behaviour is an effective way to encourage energy conservation and improve energy efficiency. Consumer behaviour is an essential issue in household energy consumption. Accordingly, this study examines households' knowledge, awareness, commitment, attitude, and behaviour towards electricity consumption, using the Seremban as a case study. This paper also focuses on assessing the relationship between knowledge, awareness, commitment, attitude, and behaviour towards electricity consumption. The empirical findings may facilitate a better understanding of where attention should be directed and the measures for long-term energy conservation, mitigation of climate change, and sustainable development.

\section{MATERIAL AND METHODS}

\section{Survey Design}

A quantitative study was conducted to analyse the behaviour of households towards sustainable electricity consumption in a rapidly growing city. The questionnaire, divided into five sections, comprises 27 items. The questionnaire seeks the respondents' socio-economic profile and knowledge, awareness, commitment, 
attitudes, and behaviour towards electricity consumption. A seven-point Likert scale was employed to produce a high correlation and $t$ value and suitability to study the electric and electronic distribution and consumption. The seven-point Likert scale also provides multiple options, allowing respondents to make a better choice for the items given. Skewness and kurtosis were run to ensure the normality of the distributed data. The value for normal distribution must be greater than 1.96 or smaller than -1.96 .

\section{Sampling Methods and Data Analysis}

The study was conducted in Seremban, a city facing a dense population and rapid urban development due to its location within the Kuala Lumpur Corridor (KLK). The samples were classified according to the type of house, i.e. single-story terrace, double-story terrace, flat, village house, or bungalow (Table 1). A household was chosen as a research unit. The questionnaires were distributed to 620 respondents, but only 400 questionnaires were returned (a $64.51 \%$ response rate). In the first stage, descriptive statistics were applied to identify the households' knowledge, awareness, commitment, attitude, and behaviour towards electricity consumption. A Pearson correlation was used to analyse the linear association between the independent and dependent variables. All the variables were treated as continuous variables.

Table 1 Samples Distribution

\begin{tabular}{lcccc}
\hline Types of Houses & $\begin{array}{c}\text { Number } \\
\text { of Area }\end{array}$ & Units & Percentage & $\begin{array}{c}\text { Total } \\
\text { Sample }\end{array}$ \\
\hline Flats & 8 & 3,385 & $3 \%$ & 15 \\
Traditional/Village & 19 & 3,320 & $3 \%$ & 20 \\
Single Story Terrace & 147 & 54,960 & $51 \%$ & 196 \\
Double Story Terrace & 69 & 25,602 & $24 \%$ & 91 \\
Detached & 26 & 10,851 & $10 \%$ & 38 \\
Bungalow & 36 & 9,654 & $9 \%$ & 40 \\
\hline TOTAL & & & 400 \\
\hline
\end{tabular}

\section{RESULTS AND DISCUSSION}

Table 2 presents the profile of the respondents. From the total number of respondents (400), 140 are male, and 260 are female. Most of the respondents $(40 \%)$ were between the age of 30 to 39 years. About $26 \%$ of the respondents were above 50, and $18.5 \%$ were between 40 to 49 years. Most of the respondents are Malay $(83 \%)$, and the rest are of other races. About $81.3 \%$ of the respondents are married, and only $14.8 \%$ are single. Seventy-three per cent $(73 \%)$ of the respondents work in the government sector, and $13.8 \%$ of respondents work in the private sector. 
Saraswathy Kasavan, Sharif Shofirun Bin Sharif Ali \& Rusinah Siron

The Behaviour of Households Towards Electricity Consumption: A Case Study at Seremban

Table 2: Demographic Characteristics of the Respondents

\begin{tabular}{llll}
\hline & & $\begin{array}{l}\text { Frequency } \\
(\mathrm{N}=400)\end{array}$ & $\begin{array}{l}\text { Percent } \\
(\%)\end{array}$ \\
\hline Gender & Male & 140 & 35 \\
& Female & 260 & 65 \\
\hline Age & $20-29$ & 42 & 10.5 \\
& $30-39$ & 180 & 40 \\
& $40-49$ & 74 & 18.5 \\
& 50 Above & 104 & 26 \\
\hline Races & Malay & 332 & 83 \\
& Chinese & 36 & 9 \\
& Indian & 24 & 6 \\
& Others & 8 & 2 \\
\hline Marital Status & Single & 59 & 14.8 \\
& Married & 325 & 81.3 \\
& Duda & 3 & 0.8 \\
& Single mother & 13 & 3.3 \\
\hline Job & Government & 292 & 73 \\
& Private & 55 & 13.8 \\
& Self-employed & 17 & 4.3 \\
& Others & 36 & 9 \\
\hline Income & $500-1000$ & 17 & 4.3 \\
& $1001-2000$ & 49 & 12.3 \\
& 2001-3000 & 83 & 20.8 \\
& 3001-4000 & 87 & 21.8 \\
& $4001-5000$ & 59 & 14.8 \\
& 5001 Above & 105 & 26.3 \\
\hline
\end{tabular}

Knowledge, Awareness, Commitment, Attitudes, and Behaviour towards

Electricity Consumption

Psychology and behaviour are essential in determining household energy consumption and conservation. This study examines the households' knowledge, awareness, commitment, attitude, and behaviour towards sustainable electricity consumption in Seremban. Knowledge is a well-known cognitive factor (thinking ability) and a significant contributing factor to constructing a social structure and creating awareness. As indicated from the analysis, the mean score for all the knowledge items towards electricity consumption was moderate, except for rebates saving electricity $(\mathrm{M}=5.79, \mathrm{SD}=1.13)$. This finding suggests that the respondents only have a moderate level of knowledge of energy-saving and environmental problems, such as greenhouse gas emissions and climate change. The respondents in the current study have a high level of knowledge of electricity consumption concerning saving money. In addition, most of them appear to have adequate knowledge of the government's rebates for saving electricity (those who consume electricity below RM20) until the end of December 2018. 
PLANNING MALAYSIA

Journal of the Malaysia Institute of Planners (2021)

In Malaysia, about 960,000 consumers from the lower-income group (those who use electricity below $91 \mathrm{kWh}$ or whose bill is below RM20 a month) enjoy free electricity (Basir et al., 2012). On 1 January 2019, the Malaysian government launched the RM40 Electric Bill Rebate Programme to replace the RM20 Electric Bill Rebate Programme. The government has allocated RM80 million for a monthly electricity bill rebate of RM40 for 185,000 domestic consumers from the lower-income group registered with the E-Kasih programme. The findings conclude that cost-saving via government initiatives is vital in influencing energy consumption knowledge among households. An electricity tariff is the amount of charge set aside by a supplier for consuming electric power for different types of customers. The tariff includes the overall cost of generating and supplying electric power at a reasonable price. In Malaysia, TNB electricity tariffs and supply voltage level classification typically depend on business activity, such as street lighting, domestic, commercial, industrial, mining, and specific agriculture. Domestic tariffs are divided into three categories: (a) $200 \mathrm{kWh}$ (1-200 $\mathrm{kWh}$ ) per month at $21.80 \mathrm{cent} / \mathrm{kWh}$; (b) $800 \mathrm{kWh}(201-1000 \mathrm{kWh})$ per month at 28.90 cents $/ \mathrm{kWh}$; and (c) over $1000 \mathrm{kWh}$ onwards per month at 31.20 cents $/ \mathrm{kWh}$ (Rahman et al., 2017). As indicated from the current analysis, the mean score for awareness for change of electricity tariff was moderate $(\mathrm{M}=4.08, \mathrm{SD}=1.76)$. Most of the households were less aware of the changes in electricity tariff.

Through the Feed-in Tariff (FiT) mechanism scheme, Malaysia has 528.06 MW of renewable energy installed capacity, which is relatively low compared to the tariffs in neighbouring countries such as Vietnam (2569 MW), Indonesia (3833 MW), and Thailand (6766 MW) (SEDA, 2019). According to Oh et al. (2010), energy demand is expected to increase by 1.2 per cent to 1.5 per cent for every one per cent growth in Malaysian GDP. This demand is rising due to the country's high economic development rate. Currently, enough electricity can be produced from fossil fuel resources (nonrenewable energy), but in the long term, fossil fuels are finite and will become costly due to their depletion. Therefore, alternative energy sources need to be considered, particularly renewable energy sources and green technology applications, to resolve multiple issues and dilemmas. Such considerations can be beneficial for present and future sustainable energy generation in Malaysia. As found in this study, the households still have moderate awareness of enough electricity supply and incentives to promote energy savings $(\mathrm{M}=5.02, \mathrm{SD}=1.31$, and $\mathrm{M}=4.90, \mathrm{SD}=1.49$, respectively).

The rapid economic and social growth has led to increasingly high energy demand in Malaysia following significant household energy consumption. Household energy consumption has contributed significantly to severe environmental problems. Substantial efforts have been made in research and development $(\mathrm{R} \& \mathrm{D})$ on energy-efficient technologies to conserve household energy consumption and reduce environmental pressures. Reducing energy demand and improving energy efficiency are widely accepted, least expensive, and 
Saraswathy Kasavan, Sharif Shofirun Bin Sharif Ali \& Rusinah Siron

The Behaviour of Households Towards Electricity Consumption: A Case Study at Seremban

quick to reduce environmental stress and climate change (Fong et al., 2008). Although technological advancements are critical to increasing energy efficiency and promoting energy conservation, the commitment of electricity consumption factors has been recognised as significant for energy conservation. As indicated from the current findings, the mean score for willingness to buy energy-efficient equipment and willing to limit energy consumption electricity was moderate $(\mathrm{M}=5.22, \mathrm{SD}=1.31$ and $\mathrm{M}=5.66, \mathrm{SD}=1.13$, respectively $)$. On the other hand, the households' willingness to reduce electricity consumption to preserve the environment is still high $(\mathrm{M}=4.71, \mathrm{SD}=1.45)$. However, the households' interest in volunteering to raise awareness of electricity consumption and saving is moderate $(\mathrm{M}=4.71, \mathrm{SD}=1.45)$. According to Teoh et al. (2020), while the public is aware of the solar energy option, they are unwilling to install solar photovoltaic panels due to the high installation costs and lack of information. Harms and Linton (2016) found that consumers are unwilling to buy energy-efficient electrical appliances due to high prices. In another study by Hast et al. (2015), they found that consumers' confusion and lack of information had hindered them from buying energy-efficient electrical appliances. Correspondingly, the households in the present study were found to have a low commitment to using energy-efficient equipment, which they considered costly. Other contributing factors were also their lack of information and environmental concerns. Those with significant environmental concerns would be more likely to buy energy-efficient appliances when encouraged.

The mean score for all the items regarding attitudes of consumption of electricity was high. Many households were aware of saving electricity to protect the environment $(\mathrm{M}=5.94, \mathrm{SD}=1.03)$ and reduce electricity tariff $(\mathrm{M}=6.15$, $\mathrm{SD}=1.01$ ). In contrast to earlier findings, no significant direct effect was found between environmental conservation attitudes and electricity consumption (Jones et al., 2015). As in the current study, most households also agreed that they are aware of controlling electricity consumption in their home $(\mathrm{M}=5.99, \mathrm{SD}=0.89)$. These findings are consistent with Kavousian et al. (2013), who found households' awareness of the need to control electricity consumption, such as buying energyefficient air conditioners and turning off lights when not in use. In other words, households consist of awareness of climate change concerns, monitoring energy consumption, and green attitudes.

The costs of household electricity depend on family members, livinglifestyle, number and age of electrical appliances, and the hours of using the electrical appliances. Most of the households surveyed felt that limiting electrical goods can save electricity $(\mathrm{M}=5.94, \mathrm{SD}=1.01)$; they were aware of electrical appliances with energy efficiency labels in Malaysia. Household electrical appliances are the largest energy consumers in Malaysia. The energy efficiency label was certified by The Energy Commission of Malaysia in 2006. Manufacturers of electrical appliances (such as domestic refrigerators, domestic fans, television, 
PLANNING MALAYSIA

Journal of the Malaysia Institute of Planners (2021)

air conditioners) need to fulfil the energy performance test standards and requirements for the star rating established by the Energy Commission. The energy efficiency label informs consumers of the predictable energy consumption of each electrical equipment based on the energy efficiency rating system. A one-star label indicates the least energy-efficient, and a five-star label is the most energy-efficient. The star rating system is a simple way for consumers to identify and select the most energy-efficient products on the market. For example, five-star-rated electrical equipment will reduce electricity consumption and better savings in the long run. This equipment also mitigates the carbon footprint from electricity generation and promotes a better quality of life with more efficient appliances. According to Ward et al. (2011), electronic appliances with the energy-star service mark usually consume $20-30 \%$ less energy than required by federal standards.

According to Aldossary et al. (2014), energy consumption behaviours towards green can reduce domestic energy consumption by $10-30 \%$. Findings from the current analysis indicate that the mean score for electricity consumption behaviour was high except for one item in the questionnaire. Three dimensions can describe a household's energy consumption behaviour: time dimension, user dimension, and spatial dimension. In the time dimension, a household's energy consumption can be defined in various time granularities, such as an hour, a day, a month, or even a year. In the user dimension, energy consumption behaviours are influenced by multiple internal factors (such as habit and environmental awareness) and external factors (such as housing characteristics and working conditions). In the spatial dimension, a household's energy consumption behaviour would influence the different residential districts, economic development, building structure, climate characteristics, and other factors. The findings suggest that most households would constantly turn off electrical appliances when not in use or before leaving their house $(\mathrm{M}=6.22, \mathrm{SD}=0.94$, and $\mathrm{M}=6.24, \mathrm{SD}=0.94$, respectively). Most households agreed to use or buy electrical appliances to save energy ( $\mathrm{M}=5.82, \mathrm{SD}=1.07$ and $\mathrm{M}=5.86, \mathrm{SD}=1.03$, respectively). However, most of them agreed that they lack information about the consumption and saving of electricity $(\mathrm{M}=5.53, \mathrm{SD}=1.14)$. This study finding suggested that sufficient information is required for consumers to take action to conserve energy. Information on environmental issues (such as carbon emissions, climate change) and efficient appliances will encourage electricity consumption towards sustainability and improve energy efficiency. Table 3 presents the overall results.

Table 3: The Behaviour of Household towards Sustainable Electricity Consumption

\begin{tabular}{lllll}
\hline Construct Items & Mean & SD & Interpretation \\
\hline $\begin{array}{ll}\text { Knowledge of the Consumption of Electricity } \\
1 \quad \begin{array}{l}\text { I understand that the use of electricity will } \\
\text { lead to climate change. }\end{array}\end{array}$ & 5.37 & 1.31 & Moderate \\
$2 \quad$ I have a high understanding of the & 5.27 & 1.17 & Moderate
\end{tabular}


Saraswathy Kasavan, Sharif Shofirun Bin Sharif Ali \& Rusinah Siron

The Behaviour of Households Towards Electricity Consumption: A Case Study at Seremban

3 I understand that consumers' use of

$5.22 \quad 1.18 \quad$ Moderate

electricity will release pollutant gases

$4 \quad$ I have an understanding of electrical

$5.57 \quad 1.03 \quad$ Moderate

appliances that save energy

5 I understand that the government provides

$5.79 \quad 1.13 \quad$ High rebates for saving electricity, particularly for the use of below RM20

\section{Awareness of Electricity Consumption}

$6 \quad$ I am aware that the electricity tariff rates in $4.08 \quad 1.76 \quad$ Moderate Malaysia does not change.

7 I am aware that the electricity supply in $\quad 5.02 \quad 1.31 \quad$ Moderate Malaysia is enough

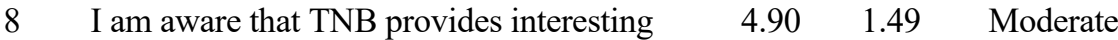
incentives to promote energy savings

Commitment of Electricity Consumption

9 I willing to buy energy-efficient equipment even though the equipment is expensive

10 I am interested in volunteering to raise awareness among the public about the consumption and saving of electricity

11 I am committed to participating in the campaign of electrical energy awareness

12 I just bought electrical appliances that save energy

13 I will reduce electricity consumption to preserve the environment.

14 I am willing to limit energy consumption $\quad 5.66 \quad 1.13 \quad$ Moderate electricity in residence.

\section{Attitudes of Consumption of Electricity}

15 I need to save electricity because it is essential to protect the environment

$5.22 \quad 1.31 \quad$ Moderate

$4.71 \quad 1.45 \quad$ Moderate

16 I have a high awareness in controlling the use of electricity in my home

17 I feel that limiting electrical goods can save electricity

18 I agree that the electricity tariff rate should be reduced

19 Electricity consumption outside peak hours is the best method to save costs and energy

\section{Behaviour of Electricity Consumption}

20 I always turn off electrical appliances when not in use

21 I use an electrical appliance to save energy

22 I always reduce energy consumption electricity

$\begin{array}{lll}5.94 & 1.03 & \text { High } \\ 5.99 & 0.89 & \text { High } \\ 5.94 & 1.01 & \text { High } \\ 6.15 & 1.01 & \text { High } \\ 5.79 & 1.12 & \text { High } \\ & & \\ 6.22 & 0.94 & \text { High } \\ 5.82 & 1.07 & \text { High } \\ 6.00 & 0.97 & \text { High }\end{array}$

\section{$5.06 \quad 1.25 \quad$ Moderate}

$5.37 \quad 1.17 \quad$ Moderate

$5.68 \quad 1.03 \quad$ High 
PLANNING MALAYSIA

Journal of the Malaysia Institute of Planners (2021)

23 I bought energy-saving equipment to reduce $5.86 \quad 1.03 \quad$ High electricity consumption.

24 I will make sure all electrical appliances are $\quad \begin{array}{lll}6.24 & 0.94 & \text { High }\end{array}$ turned off before leaving the house.

25 I always remind family members to save $\quad 6.18 \quad 0.89 \quad$ High energy consumption.

26 I always practice saving behaviour at the $\quad \begin{array}{lll}6.23 & 0.87 & \text { High }\end{array}$ house.

27 I always get information about consumption $\quad 5.53 \quad 1.14 \quad$ Moderate and saving of electricity.

Direct and Indirect Relationship towards Electricity Consumption

Pearson correlation was employed to investigate the relationship between the independent and the dependent variables (Table 4). We tested the score of knowledge, awareness, commitment, and attitude as the independent variables, while behaviour scores towards electricity consumption as the dependent variable. From the analysis, we found that the scores of knowledges, awareness and household commitment are positively correlated. The commitment was found to have the most significant correlation coefficient $(r=0.506 p<0.01)$, followed by awareness towards knowledge of households $(r=0.398 p<0.01)$. The attitude was found to correlate with behaviour $(\mathrm{r}=0.750 \mathrm{p}<0.01)$ significantly. These findings suggest that the households who expressed a positive attitude were more likely to engage in a positive behaviour towards electricity consumption than those who did not have a positive attitude.

The current study suggests that a person's positive behaviour towards electricity consumption relies heavily on his/her positive knowledge, awareness, commitment, and attitude. These findings corroborate Rahman et al. (2017), who found a positive correlation between knowledge and awareness to implement an energy-efficient approach for using electrical appliances among households. Also found in the present study is that the electricity consumption in Seremban depends highly on the households' level of knowledge and commitment.

Table 4 Direct and Indirect Interaction of Variables and Electricity Consumption $(\mathrm{kWh})$

\begin{tabular}{lccccc}
\hline & Knowledge & Awareness & Commitment & Attitude & Behaviour \\
\hline Knowledge & 1 & & & & \\
Awareness & $0.398^{* *}$ & 1 & & & \\
& & & & & \\
Commitment & $0.506^{* *}$ & $0.451^{* *}$ & 1 & & \\
Attitude & $0.506^{* *}$ & $0.284^{* *}$ & $0.511^{* *}$ & 1 & \\
Behaviour & $0.531^{* *}$ & $0.257^{* *}$ & $0.502^{* *}$ & $0.750^{* *}$ & 1 \\
\hline
\end{tabular}

** Significant at 0.01level (2-tailed)

*Total electricity consumption per month (kWh/month) 
Saraswathy Kasavan, Sharif Shofirun Bin Sharif Ali \& Rusinah Siron

The Behaviour of Households Towards Electricity Consumption: A Case Study at Seremban

\section{CONCLUSIONS}

This study has highlighted the complexity of household energy consumption by investigating households' knowledge, awareness, commitment, attitude, and behaviour. The households were found with low commitment to using energyefficient appliances due to the high cost compared to non-energy-efficient appliances, despite environmental concern. Cost savings via government initiatives were also found to influence energy conservation among households. The finding suggests that the government and power companies should enforce regulations and technological advances to promote energy conservation and improve energy efficiency among households. For example, increasing renewable energy (biomass, biogas, and solar) as alternative energy that is less dependent on fossil fuel is one of the best approaches to reducing greenhouse gas emissions and creating longterm sustainable energy consumption. The findings also suggest that the government and power companies consider consumers' economic status and lifestyle as these factors are closely related to their energy behaviours. For example, electricity consumption will increase as family members grow; more appliances will be used, and longer usage will occur, including less-efficient appliances. Also, most households felt that limiting electrical goods could save electricity and consider having electrical devices with the Malaysian energy efficiency label. The implication is that the government and power companies should encourage households to highly energy-efficient electrical appliances based on the energy star rating to conserve energy.

\section{ACKNOWLEDGEMENT}

The research has been funded by School of Government (SOG), Universiti Utara Malaysia (UUM) under Geran Universiti with SO Code: 21051

\section{REFERENCES}

Aldossary, N. A., Rezgui, Y., \& Kwan, A. (2014). Domestic energy consumption patterns in a hot and humid climate: A multiple-case study analysis. Applied Energy, 114, 353-365. https://doi.org/10.1016/j.apenergy.2013.09.061

Basir, K. H., Burke, P. J., Kurniawati, S., Hamid, K. A., Rashid, Z. A., Abdul, K., Zakariah, H., \& Rashid, A. (2012). How Will the New Tariff Structure Benefit. ERIA Research Project Report, 2035(August), 207-252.

Chen, Y. T. (2017). The factors affecting electricity consumption and the consumption characteristics in the residential sector - a case example of Taiwan. Sustainability (Switzerland). https://doi.org/10.3390/su9081484

Energy Commission. (2021). Malaysia Energy Information Hub. Economic Data Analysis: Energy Indicator-Energy Intensity per Capita. Suruhanjaya Tenaga. https://meih.st.gov.my/statistics

Fong, W. kean, Matsumoto, H., Ho, C. S., \& Lun, Y. F. (2008). Energy consumption and carbin dioxide emission considerations in the urban planning process in Malaysia. Planning Malaysia, VI, 99-128. 
Harms, R., \& Linton, J. D. (2016). Willingness to Pay for Eco-Certified Refurbished Products: The Effects of Environmental Attitudes and Knowledge. Journal of Industrial Ecology, 20(4), 893-904. https://doi.org/10.1111/jiec.12301

Hast, A., Alimohammadisagvand, B., \& Syri, S. (2015). Consumer attitudes towards renewable energy in China - The case of Shanghai. Sustainable Cities and Society. https://doi.org/10.1016/j.scs.2015.04.003

Jones, R. V., Fuertes, A., \& Lomas, K. J. (2015). The socio-economic, dwelling and appliance related factors affecting electricity consumption in domestic buildings. In Renewable and Sustainable Energy Reviews. https://doi.org/10.1016/j.rser.2014.11.084

Kavousian, A., Rajagopal, R., \& Fischer, M. (2013). Determinants of residential electricity consumption: Using smart meter data to examine the effect of climate, building characteristics, appliance stock, and occupants' behavior. Energy, 55, 184-194. https://doi.org/10.1016/j.energy.2013.03.086

Permana, A. S., Aziz, N. A., \& Jaffar, A. R. (2013). Potential urban development parameters that reduce energy consumption in residential area. Planning Malaysia, II, !01-118.

Rahman, K. A., Leman, A. M., Mubin, M. F., Yusof, M. Z. M., Hariri, A., \& Salleh, M. N. M. (2017). Energy Consumption Analysis Based on Energy Efficiency Approach. Faculty of Mechanical \& Manufacturing Engineering, Universiti Tun Hussein Onn Malaysia, 02003.

SEDA. (2019). Sustainable Energy Development Authority Malaysia. SEDA: Putrajaya, Malaysia. http://www.seda.gov.my/

Teoh, A. N., Go, Y. I., \& Yap, T. C. (2020). Is Malaysia Ready for Sustainable Energy? Exploring the Attitudes toward Solar Energy and Energy Behaviors in Malaysia. World, 1(2), 90-103. https://doi.org/10.3390/world1020008

Ward, D. O., Clark, C. D., Jensen, K. L., Yen, S. T., \& Russell, C. S. (2011). Factors influencing willingness-to-pay for the ENERGY STAR $®$ label. Energy Policy, 39(3), 1450-1458. https://doi.org/10.1016/j.enpol.2010.12.017

Yalcintas, M., \& Kaya, A. (2017). Roles of income, price and household size on residential electricity consumption: Comparison of Hawaii with similar climate zone states. Energy Reports. https://doi.org/10.1016/j.egyr.2017.07.002

Yong, Z. J., Bashir, M. J. K., Ng, C. A., Sethupathi, S., Lim, J. W., \& Show, P. L. (2019). Sustainable waste-to-energy development in Malaysia: Appraisal of environmental, financial, and public issues related with energy recovery from municipal solid waste. Processes, 7(10). https://doi.org/10.3390/pr7100676

Aldossary, N. A., Rezgui, Y., \& Kwan, A. (2014). Domestic energy consumption patterns in a hot and humid climate: A multiple-case study analysis. Applied Energy, 114, 353-365. https://doi.org/10.1016/j.apenergy.2013.09.061

Basir, K. H., Burke, P. J., Kurniawati, S., Hamid, K. A., Rashid, Z. A., Abdul, K., Zakariah, H., \& Rashid, A. (2012). How Will the New Tariff Structure Benefit. ERIA Research Project Report, 2035(August), 207-252.

Chen, Y. T. (2017). The factors affecting electricity consumption and the consumption characteristics in the residential sector - a case example of Taiwan. Sustainability (Switzerland). https://doi.org/10.3390/su9081484

Energy Commission. (2021). Malaysia Energy Information Hub. Economic Data Analysis: Energy Indicator-Energy Intensity per Capita. Suruhanjaya Tenaga. 
Saraswathy Kasavan, Sharif Shofirun Bin Sharif Ali \& Rusinah Siron

The Behaviour of Households Towards Electricity Consumption: A Case Study at Seremban

https://meih.st.gov.my/statistics

Fong, W. kean, Matsumoto, H., Ho, C. S., \& Lun, Y. F. (2008). Energy consumption and carbin dioxide emission considerations in the urban planning process in Malaysia. Planning Malaysia, VI, 99-128.

Harms, R., \& Linton, J. D. (2016). Willingness to Pay for Eco-Certified Refurbished Products: The Effects of Environmental Attitudes and Knowledge. Journal of Industrial Ecology, 20(4), 893-904. https://doi.org/10.1111/jiec.12301

Hast, A., Alimohammadisagvand, B., \& Syri, S. (2015). Consumer attitudes towards renewable energy in China - The case of Shanghai. Sustainable Cities and Society. https://doi.org/10.1016/j.scs.2015.04.003

Jones, R. V., Fuertes, A., \& Lomas, K. J. (2015). The socio-economic, dwelling and appliance related factors affecting electricity consumption in domestic buildings. In Renewable and Sustainable Energy Reviews. https://doi.org/10.1016/j.rser.2014.11.084

Kavousian, A., Rajagopal, R., \& Fischer, M. (2013). Determinants of residential electricity consumption: Using smart meter data to examine the effect of climate, building characteristics, appliance stock, and occupants' behavior. Energy, 55, 184-194. https://doi.org/10.1016/j.energy.2013.03.086

Permana, A. S., Aziz, N. A., \& Jaffar, A. R. (2013). Potential urban development parameters that reduce energy consumption in residential area. Planning Malaysia, II, !01-118.

Rahman, K. A., Leman, A. M., Mubin, M. F., Yusof, M. Z. M., Hariri, A., \& Salleh, M. N. M. (2017). Energy Consumption Analysis Based on Energy Efficiency Approach. Faculty of Mechanical \& Manufacturing Engineering, Universiti Tun Hussein Onn Malaysia, 02003.

SEDA. (2019). Sustainable Energy Development Authority Malaysia. SEDA: Putrajaya, Malaysia. http://www.seda.gov.my/

Teoh, A. N., Go, Y. I., \& Yap, T. C. (2020). Is Malaysia Ready for Sustainable Energy? Exploring the Attitudes toward Solar Energy and Energy Behaviors in Malaysia. World, 1(2), 90-103. https://doi.org/10.3390/world1020008

Ward, D. O., Clark, C. D., Jensen, K. L., Yen, S. T., \& Russell, C. S. (2011). Factors influencing willingness-to-pay for the ENERGY STAR ${ }$ label. Energy Policy, 39(3), 1450-1458. https://doi.org/10.1016/j.enpol.2010.12.017

Yalcintas, M., \& Kaya, A. (2017). Roles of income, price and household size on residential electricity consumption: Comparison of Hawaii with similar climate zone states. Energy Reports. https://doi.org/10.1016/j.egyr.2017.07.002

Yong, Z. J., Bashir, M. J. K., Ng, C. A., Sethupathi, S., Lim, J. W., \& Show, P. L. (2019). Sustainable waste-to-energy development in Malaysia: Appraisal of environmental, financial, and public issues related with energy recovery from municipal solid waste. Processes, 7(10). https://doi.org/10.3390/pr7100676 